\title{
IV. 肺炎治療の進歩と実際
}

\section{1. 抗菌薬療法の考え方〜PK-PD理論〜}

\section{藤村 茂 渡辺 彰}

要旨

抗菌薬適正使用は, 副作用の軽減と最良の臨床効果を得るだけでなく, 薬剤耐性菌の出現抑制や医療経 済効果にも寄与するが, 適正使用の実施にはPK-PD理論の活用が不可欠となる。また細菌感染症の治療で は, 多数の抗菌薬を効果的に使い分けることが求められることから, 各薬剤の特徵や抗菌力, アンチバイ オグラムによる状況把握, さらには当該薬剤の耐性化について知ることが, 適正使用の実践につながる.

〔日内会誌 $100 ： 3533 \sim 3541 ， 2011$ ]

Key words PK-PD理論, 市中肺炎, 院内肺炎, 薬剂耐性菌

はじめに

近年, 抗菌薬の適正使用というキーワードを よく耳にする。一般に感染症化学療法では, 起 炎菌を想定し，それに対し高い抗菌力を示す薬 剂が選択されるが, こうした抗菌力は, 培地上 すなわちin vitroの成績である。一方, 感染症の 感染病巣は, 呼吸器, 尿路, 皮膚・軟部組織な ど多岐にわたることから，抗菌薬には優れた組 織移行性が求められる。しかしながら全ての抗 菌薬で組織移行の成績が揃つているわけではな い. そのため薬物血中濃度をべースに薬物体内 動態と各薬剤の特徴から適切な用法・用量を考 えるPharmacokinetics-Pharmacodynamics (PK-
PD) 理論が, 今日の抗菌薬適正使用の根幹となっ てきている。本稿では, 呼吸器感染症に対して PK-PD理論に基づき抗菌薬をどう使っていくの かについて述べたい.

\section{PK-PD理論の意義}

PK-PD理論を提唱したCraig博士は, 抗菌薬に は, 濃度を高めることで殺菌効果を示す濃度依 存性タイプと菌の最小発育阻止濃度 (MIC) 以上 を出来るだけ長い時間維持することで効果を発 揮する時間依存性タイプがあることを示した(図 1).これを受けて, 最適な抗菌薬治療に際し, AUC/ MIC, Cmax/MIC, Time above MIC (\% TAM) の 3 つのPK-PDパラメータを考慮する必要性を

東北大学加龄医学研究所抗感染症薬開発研究部門

Diagnosis and treatment of pneumonia-Progress of the guidelines for treatment of pneumonia in Japan. Topics : IV. Progress and the current status of the treatment of pneumonia: 1. Strategy of antimicrobial chemotherapy considering pharmacokinetic-pharmacodynamic parameters for respiratory tract infection.

Shigeru Fujimura and Akira Watanabe : Research Division for Development of Anti-Infective Agents, Institute of Development, Aging and Cancer, Tohoku University, Japan. 


\section{トピックス}
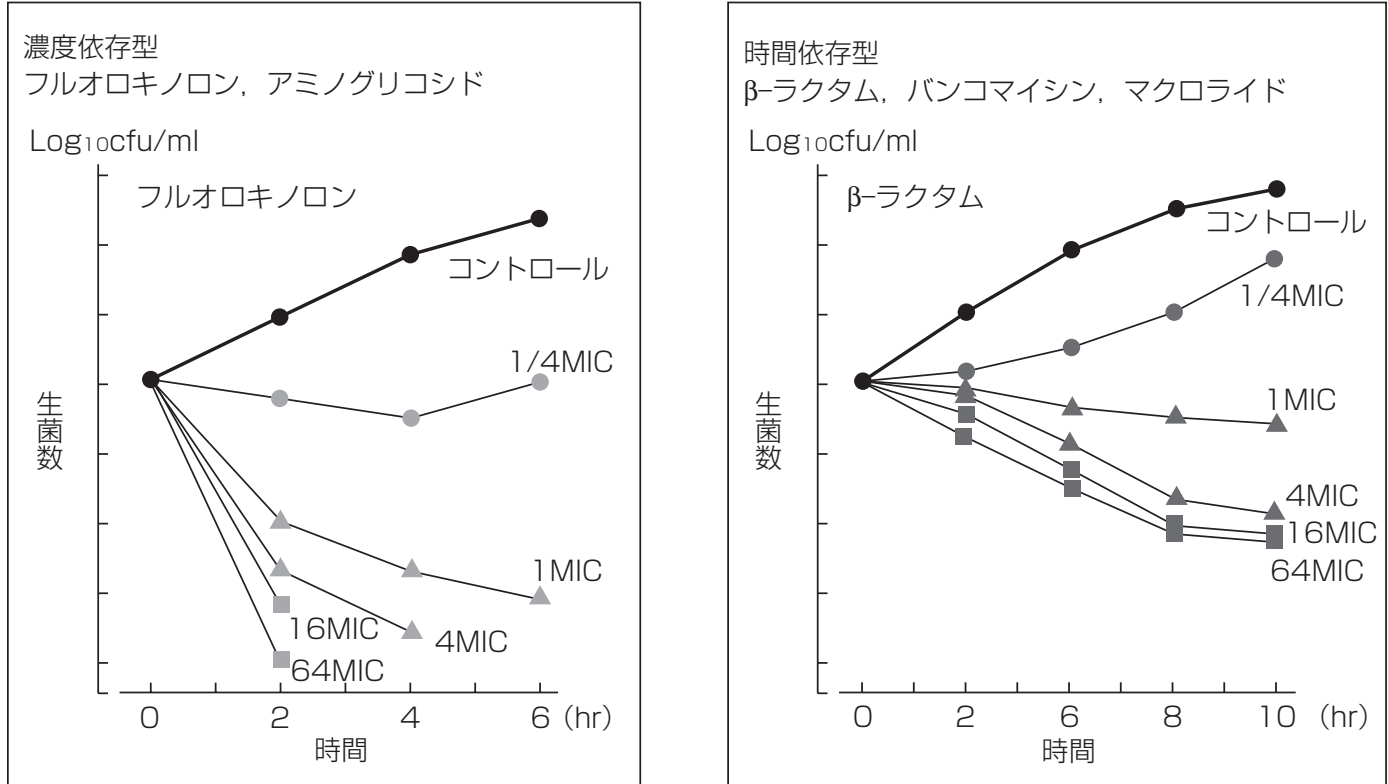

図 1. 各抗菌薬の抗菌力発現のタイプ1)

フルオロキノロン系薬等は濃度を高くするほど殺菌効果が高い（左図）

一方， $\beta$ ラクタム系薬等は，ある一定濃度（4MIC）以上で殺菌効果の上昇は止まりむしろ，その濃度を 維持させることで高い殺菌効果が得られる（右図）

唱えた (図 2)。前者 2 つは, 濃度依存性で抗菌 力を示す薬剤の関連パラメータになり, \% TAM は, 時間依存性すなわち 24 時間あたり最小発育 阻止濃度（MIC）を超える薬物血中濃度を出来 るだけ高い割合で維持する投与法が求められる 薬剤に関連する ${ }^{1)}$.

これら 3 つのパラメータは, 全てMICをべー スに考えられており, 血中濃度のピーク值（最 高血中濃度), MIC以上の血中濃度を維持する時 間やトラフ值, 血中濃度-時間曲線下面積 (area under the curve : AUC) との関係から, 抗菌薬 の各系統によって, それぞれ抗菌効果を最大限 発揮するために必要なパラメータが異なってい る.

呼吸器感染症に汎用される薬剤としてレスピ ラトリーキノロン系薬やマクロライド系薬など の関連パラメータは AUC/MICである.これらの 薬剂は濃度依存性の抗菌作用を有し, かつ持続
効果が長い特徴を有する. Cmax/MICと相関す る薬剤は, 呼吸器科領域では第一次選択となる ことは少ないアミノグリコシド系抗菌薬である2). レスピラトリーキノロン系薬は, 前述のAUC/ $\mathrm{MIC} と も に \mathrm{Cmax} / \mathrm{MIC}$ 関連パラメータであ ると考えられている。一方，\% TAMが関連パラ メータとなるのは, ペニシリン系, セファロス ポリン系, カルバペネム系などの $\beta$ ラクタム系 抗菌薬である。但し, 最近の研究からカルバぺ ネム系のオラペネムだけは，その関連パラメー タは\% TAMではなく, AUC/MICであるとの報 告がある ${ }^{3)}$. 今後, 用法用量と臨床効果との関係 について検討されることにより，従来の関連パ ラメータが薬剤毎に変更されることがあるかも しれない。 


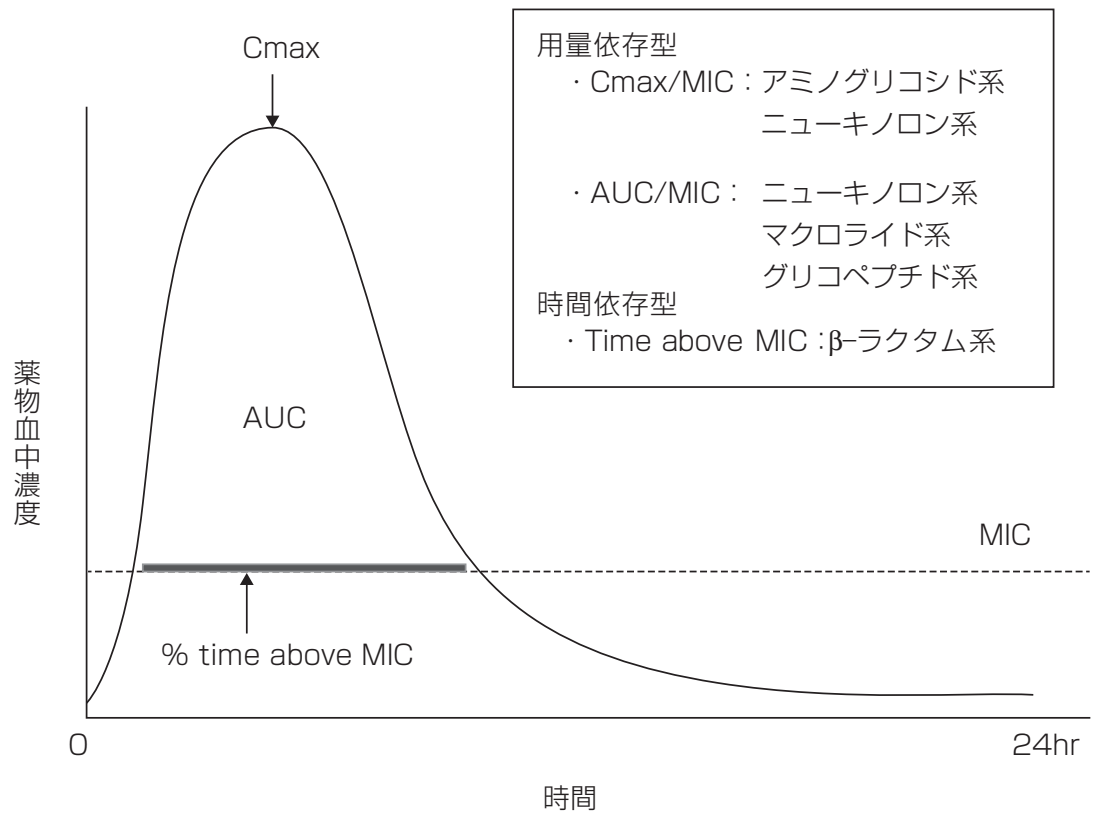

図 2. 各種抗菌薬に関連するPK-PDパラメータ

\section{2. 臨床におけるPK-PD理論}

PK-PD理論が発表された 1998 年の遥か以前か ら, 抗菌化学療法は実施されてきており, PK$\mathrm{PD}$ 理論が無くとも多くの感染症患者を救ってき た事実がある。すなわち，これまでの抗菌薬治 療で今後も同様の治療成績を保つことは可能で ある. しかしながらPK-PD理論は, 従来の投与 法で苦慮する重症感染症で, 最も有効に活用さ れる。

PK-PD理論の応用には, (1)起炎菌の同定, (2) 抗菌薬のMICの測定, (3)抗菌薬の体内動態といっ た情報が必要である。これらの実施には，相当 な設備と専門家の配置が不可欠であり，大学病 院や基幹病院などでなければ現実には困難であ る。但し，こうした重症患者の多くは，前述の ような病院で治療を受けることから，これらの 病院では本理論の活用は必須である.

\section{PK-PD理論は耐性菌を抑制する}

前項で述べたようにPK-PD理論は基幹病院な どで活用されるべきで医院・クリニックなどの 第一次医療機関では関係ない...というわけでは ない.一般に一次医療機関では経口抗菌薬が汎 用される。抗菌薬耐性菌は, その薬殽の至適濃 度より低濃度が長い時間維持された場合に出現 しやすい。これはmutant selection window （MSW）仮説と呼ばれ, 抗菌薬によって各種細 菌の発育が抑制される濃度と完全に死滅する濃 度に挟まれた濃度域に薬物血中濃度が比較的長 時間保持されると耐性株が選択されるというも のである（図 3)。しかし実際には薬剂耐性菌の 選択は, MICより低い濃度 $(1 / 2 \mathrm{MIC})$ でも選択さ れる4)。また最近では, 更に低い濃度でも耐性菌 数が感受性菌数より上回ることが報告された ${ }^{5)}$. すなわち, MICより低濃度も臨床的にMSWと考 えるべきである. 


\section{トピックス}

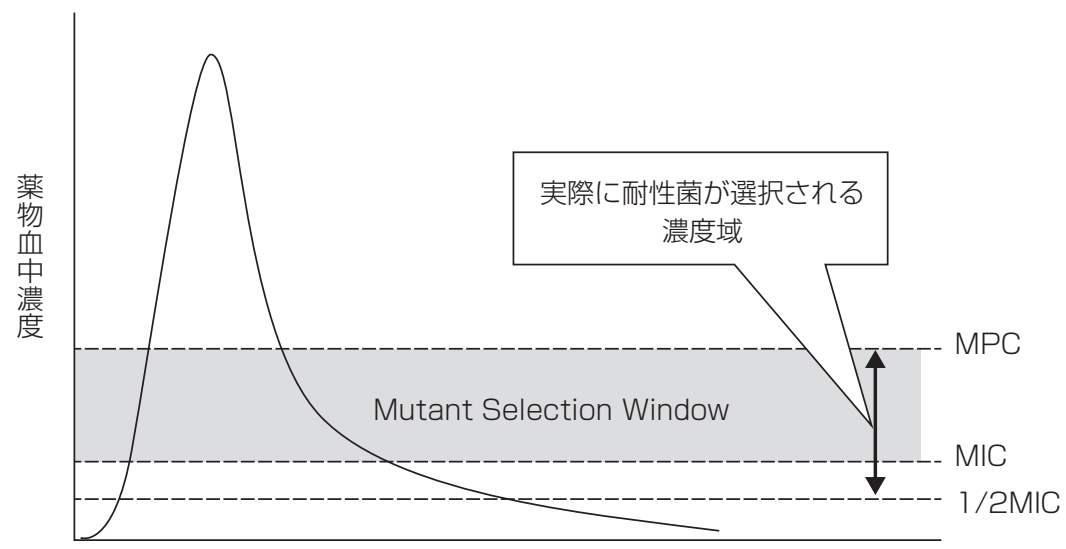

時間

図 3. 耐性菌が選択される濃度域はMutant Selection Window（MSW）よ り広い

従来の抗菌薬療法は, 比較的安全性を重視す るあまり低用量の投与を続けることがあったが, これは副作用が少ない半面, 臨床的殺菌効果も 低く, 結果的に抗菌薬の長期投与が必要になり, 医療経済的にもマイナスとなる。これに加えて 薬片耐性菌を容易に選択してしまうのである.

今日の医療制度では，患者は，重症度に応じ 一次医療機関から高次医療機関へ紹介されるシ ステムとなっている. 高次医療機関では, MRSA や多剂耐性グラム陰性菌による院内感染が問題 になっているが, こうした院内感染を減少させ るためには, 院内感染制御と抗菌薬適正使用に よる耐性菌出現抑制の両輪が軸となる. 一次医 療機関においても抗菌薬の適正使用が, 我が国 の耐性菌対策の重要なカギとなる.

\section{PK-PD理論のweak point}

ここ数年で我が国でもPK-PD理論が，急速に 認知されるようになったが, 臨床で充分に活用 されているかは疑問が残る．PK-PD理論の説明 として関連パラメータや効果と相関する薬郕と して図 2 に示されるグラフがよく用いられる.
こうしたグラフは, 一般に抗菌薬の開発時に検 討された健常人の薬剤投与 24 時間の血中濃度曲 線を基にしている.すなわち, 患者の病態や年 齢等は各自で考慮しなければならない. 抗MRSA 薬など一部の抗菌薬では, 薬物血中濃度解析シ ステムがあり，患者個々に合致した薬物動態を 示すことが出来るが，これ以外は医師の経験に よるところが大きい，1.に述べたように，PK$\mathrm{PD}$ 関連パラメータは全て抗菌薬の対象菌に対す るMIC值がベースになっているが，実際にMIC 值を測定している施設は, 極めて少ないことが 問題である。またクリニック等の一次医療機関 の場合, 自施設に検査室を持たないことから細 菌検査などを外部検査機関に依頼していること が多い. 従って担当医が検査成績の情報を得る までに2〜3 日のタイムラグを生じてしまう.こ うしたことから呼吸器感染症や尿路感染症の疑 いであっても, 細菌検査をオーダーすることは 少ないのが現状である. 薬剤耐性菌の出現抑制 には，病院だけでなく日本の医療を支える一次 医療機関における抗菌薬適正使用が重要である が，こうした機関で如何にPK-PD理論を活かし ていくのかが今後の課題である. 


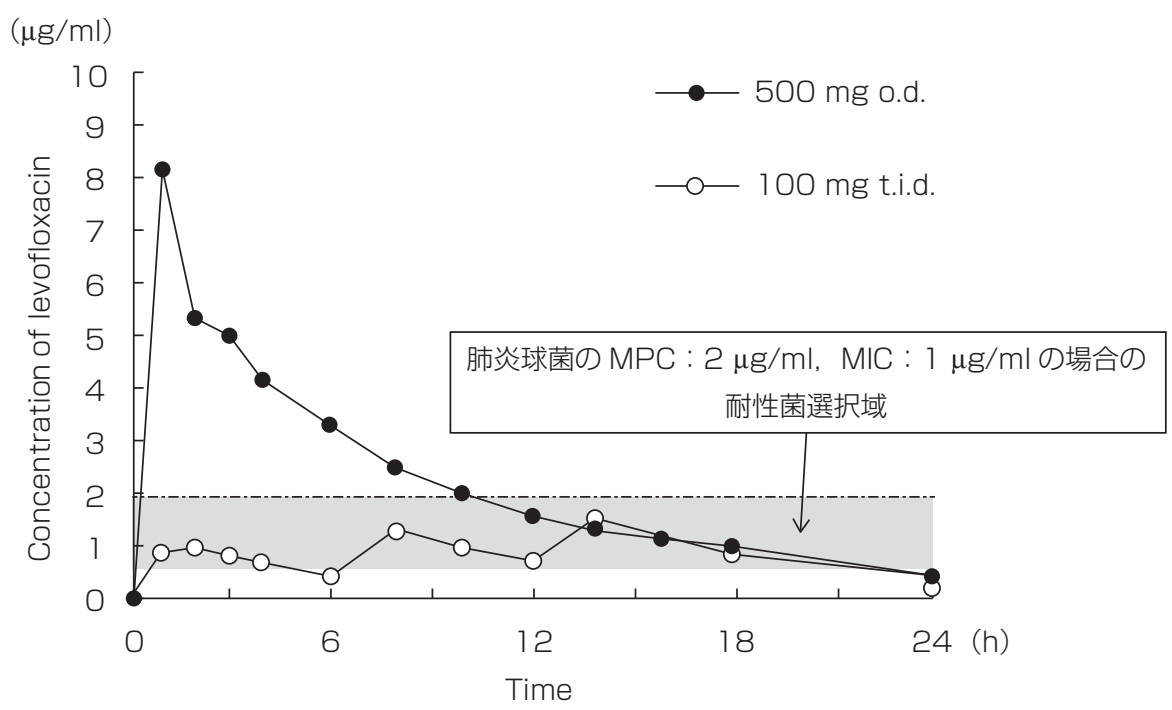

図 4. レボフロキサシンの用法用量別血中濃度推移と耐性菌選択域

\section{5. 一次医療機関におけるPK-PD理論の活 用}

医院・クリニックなどの一次医療機関と二次・ 三次医療機関の病院との違いとして，採用され ている薬品数があげられる. 現在の医薬分業シ ステムでは，患者が自由に薬局を選べることか ら, 医師は基本的に全ての医薬品を処方するこ とが可能である。しかしながら実際には，医院 の近隣（門前）にある薬局に配置される薬片が 処方されている. 一方, 薬局からすると, どこ の医療機関の処方箋も受付可能であるが, 近隣 の医院より処方され易い薬剤以外をストックし ていることは殆どない. したがって他施設から 処方された薬剤は，その場で薬剤を取り寄せる ことになり，結果として患者を待たせることに なるのである。こうしたことの無いよう医院と 近隣薬局は，準備する薬剤を決めておくが，一 般に選択できる抗菌薬は少ないのが現状である. すなわち，ある程度偏った抗菌薬が使用され， また外来患者であることから経口抗菌薬のコン
プライアンスが保たれているか把握することは 困難となる．以上 2 点は耐性菌出現に関係する 可能性が高いことから,一次医療機関こそ, PK$\mathrm{PD}$ 理論を応用し, 薬用量を可能な限り高くし, 対象菌を一気に吒く「高用量短期間投与」を行 うことが肝要である。

経口広域抗菌薬としてフルオロキノロン系の 薬剤が汎用されているが，レボフロキサシンや ガレノキサシン，モキシフロキサシンなど特に 呼吸器感染症に有効性が高いものはレスピラト リーキノロンと呼ばれている。 これらのレスピ ラトリーキノロンは, PK-PD理論が考慮されて おり, 高用量であるが, 投与回数を 1 日 1 回に することで高い有効性を示し, 耐性菌の出現抑 制も期待されている（図 4)。このようにPK-PD 理論が考慮された薬片の使用が重要なカギとな る. 


\section{PK-PD理論が考慮された抗菌薬}

\section{1) フルオロキノロン系薬(レスピラトリーキ} ノロン)

レスピラトリーキノロンとは, 呼吸器各組織 への移行が高率であり, かつ呼吸器感染症の起 炎菌として重要な肺炎マイコプラズマや肺炎ク ラミジアなどの非定型菌に加えて細菌性肺炎の 起炎菌として最も高頻度で重症化し易い肺炎球 菌にも有効なニューキノロン系薬である。レボ フロキサシン $(500 \mathrm{mg})$ ，ガレノキサシン，モキ シフロキサシンは特に高いCmaxを示し, 血中半 減期 $(\mathrm{T} 1 / 2)$ も長いことから，これらの薬郕で は 1 日 1 回の投与が可能である. 上記 3 剤に加 えトスフロキサシンは, 高いAUC值を示す.フ ルオロキノロン系薬のPK-PD関連パラメータは $\mathrm{AUC} / \mathrm{MIC} し く は \mathrm{Cmax} / \mathrm{MIC}$ あるるこから, これらのレスピラトリーキノロンは有効性が高 く, 特に高用量単回投与の薬剤は, 耐性菌が選 択されにくくなっている.

レスピラトリーキノロンは, 肺組織(肺実質) への移行性は血中の 2 倍以上の濃度で移行する 薬剤が多く, 中でもレボフロキサシン $(500 \mathrm{mg})$ とモキシフロキサシンの対血清比は 4 倍以上を 示すため, 肺炎診療における適応は高い6).

\section{2）マクロライド系抗菌薬}

従来のアジスロマイシン $500 \mathrm{mg}$ に加え, 2009 年より $2 \mathrm{~g}$ 単回投与のドライシロップ製剤である ジスロマック $\mathrm{SR}^{\circledR}$ (ファイザー)が使用されてい る.これもPK-PD理論を応用した薬剤であり, $2 \mathrm{~g}$ 単回服用するだけで, これまでの 1 日 1 回 $500 \mathrm{mg} 3$ 日間服用時と同等以上の抗菌効果が 期待されている.これは投与初期より高い血中 濃度を示す（フロントローディング）ことで投 与初期より高い抗菌効果が得られる。すなわち 急性感染症に対応可能な薬剤である。このフロ ントローディングにより,これまで 14 員環と 16
員環マクロライド系薬で高頻度の耐性化が問題 となっている肺炎球菌 (PRSP, PISP含) やイン フルエンザ菌（BLNAR含）を起炎菌とした市中 肺炎の有効率が症例数は少ないものの $100 \%$ を 示している。本剤は組織移行性に優れて, かつ 単回投与であるので服薬コンプライアンスは 100\% が見込める.これまでの内服薬でほとんど みられなかった白血球への移行性を従来品より 2〜3 倍高めたことにより, 組織移行性というよ り, むしろ感染病巣部への移行性が高い.

ジスロマック $\mathrm{SR}^{\circledR}$ は単回高用量投与であるた め, 最も注意すべき点は胃腸障害の副作用であ り, 中でも下痢の出現頻度が $16.4 \%$ と高い.こ の下㾥は平均して 2.2 日で消失する. マクロライ ド系薬による下痢の副作用は，濃度依存性の局 所作用によるものであり，他の抗菌薬にみられ る腸内細菌叢の乱れに起因するものは少ないこ とから，整腸剤の併用で対処できるものではな い。すなわち，本剤使用にあたり患者へ下痢の 副作用が出現する可能性が高い旨を説明の上, 投薬することが重要である.

\section{3) 抗MRSA薬}

（1）リネゾリド

リネゾリドは, 腎機能障害における薬物動態 の変化が少なく腎機能障害合併例であっても薬 物血中濃度モニタリング（TDM）を考慮せずに 投与することが可能な薬剂である。組織移行性 に優れており，特に肺組織への移行性が良好で あることからMRSA肺炎治療に期待が高い，

リネゾリドの主な副作用として骨髄抑制があ げられ, 2 週間以上の投与期間で発現頻度が増加 する一方, 投薬を中止すると回復する. 従って, リネゾリドの投与にあたっては，投与期間を最 小限に留めることと週 1 回を目処に定期的な血 液検査の実施が必要である。抗MRSA薬の中で 唯一, 経口投与が認められており静脈注射と比 較して最高血中濃度に違いがみられるが投与 2 時間以降の血漿中濃度の推移は同等である。食 


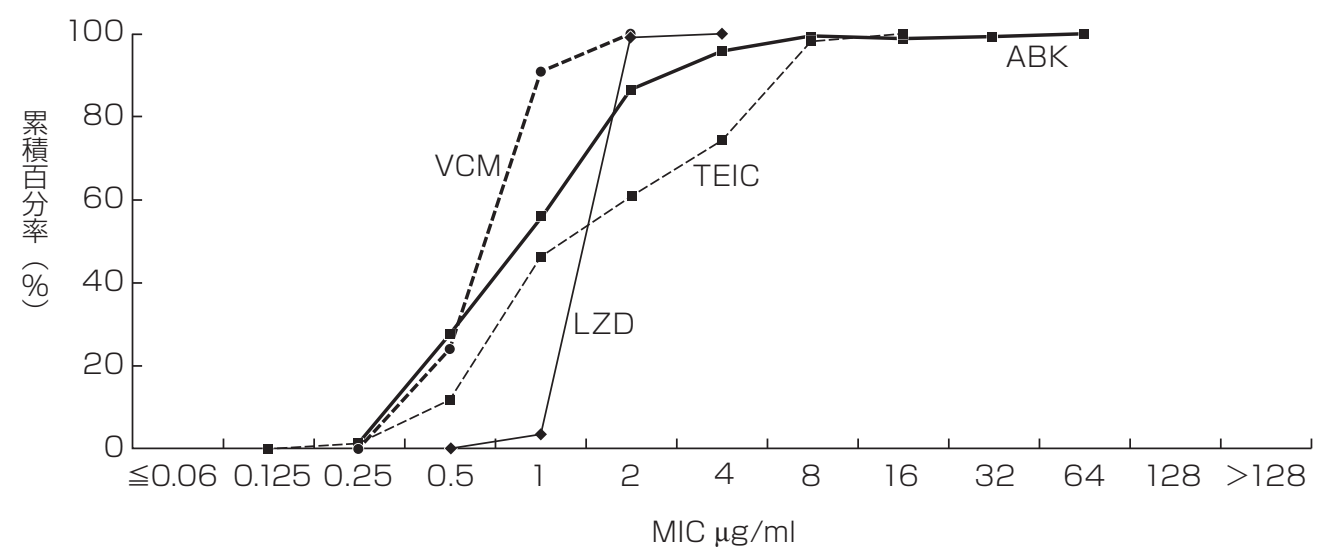

図 5. 2010 年度東北地区で分離されたMRSA 121 株の薬剤感受性分布

事の影響は多少あるものの，殆ど気にせず 12 時間毎の投与により, 静脈内投与と同等の効果 が期待される.

(2) 塩酸バンコマイシン

塩酸バンコマイシンは, グラム陽性菌に抗菌 力を有するが, 我が国の保険適用はMRSAによ る各種感染症のほか, 注射薬ではペニシリン耐 性肺炎球菌による敗血症にも使われる.

抗MRSA薬の中で最も早くTDMが導入され, 多くの医療機関でバンコマイシンのTDMが実施 されている.このTDM解析によると, MICが 2 $\mu \mathrm{g} / \mathrm{ml}$ のバンコマイシン低感受性MRSAの場合, PK-PD理論から, その有効性が期待できない可 能性が指摘されている7 .2010 年の我々の調査で は, MICが $2 \mu \mathrm{g} / \mathrm{ml}$ を越えるMRSA臨床分離株の 分離頻度が $10 \%$ 程度であった（図 5）が, こう したケースでは他薬を選択すべきである。

(3）テイコプラニン

テイコプラニンは, バンコマイシンょり (1)有 効治療域への到達が遅い(2)血中濃度半減期が約 10 倍長いことから, 初回投与時は必ず負荷投与 （ローディングドーズ）し，以降の投与は 1 日 1 回の投与で血中濃度を維持させる.

臨床的有効性は, AUC/MICとの関連性を示す 報告はほとんどなく，血中トラフ值 $10 \mu \mathrm{g} / \mathrm{ml}$
以上（重症例 $20 \mu \mathrm{g} / \mathrm{ml}$ 以上）の維持が求められ る. 腎障害などの副作用は, $60 \mu \mathrm{g} / \mathrm{ml}$ 以上の血 中トラフ值に依存すると考えられており, 臨床 ではこのトラフ值を示すことは考えにくく，腎 機能に対する影響はバンコマイシンやアルベカ シンに比して少ない.

最近, テイコプラニンの後発医薬品の中に血 中動態が先発品と同等とはいえない薬品がある 可能性が報告8)され, PK-PD理論に基く抗菌薬治 療において後発抗菌薬の在り方が今後の検討課 題になるだろう.

（4）硫酸アルベカシン

アルベカシンのPK-PD関連パラメータは Cmax/MICであり, 投与初日からすみやかに菌 数を減少させ, 殺菌効果が得られやすい薬郕で ある．副作用の発現リスクを抑えるため，血中 トラフ濃度を $\leqq 2 \mu \mathrm{g} / \mathrm{ml}$ に設定する必要があると 考えられている. また抗MRSA薬の中で唯一, グラム陽性菌のみならずグラム除性菌にも抗菌 活性を有する薬郕であり, 筆者らは, in vitroの 成績で緑膿菌に対しゲンタマイシンと同等でア ミカシンより優れた抗菌力を示すことを報告し た.さらにメタロー $\beta$ さラクタマーゼ産生株にも比 較的良好な抗菌力を示すことを確認している ${ }^{9}$. 
4） $\beta$ ラクタマーゼ阻害薬配合ペニシリン系薬

（1）タゾバクタム/ピペラシリン

防ラタム系抗菌薬のPK-PD関連パラメータ は時間依存性であることから，最適な抗菌作用 と関連するパラメータは適応菌に対する最小発 育阻止濃度 (MIC) 以上の薬剂濃度を示す時間 (time above MIC : TAM) であり，24 時間の中 で薬物血中濃度がMICを超えている時間の割合 が\% TAMと定められている.ペニシリン系薬が 各種細菌に対し, 臨床的に有効な抗菌力を示す \% TAMの目標值として $30 \%$ 以上で増殖抑制作 用があり， $50 \%$ 以上で最大殺菌作用を示す．ピ ペラシリンでは緑膿菌やAcinetobacter属に対し て\%TAMが目標值より低值を示すが, タゾバク タム/ピペラシリンのMICが各菌に対して $32 \mu \mathrm{g} /$ $\mathrm{ml}, 8 \mu \mathrm{g} / \mathrm{ml}$ のとき, いずれも目標值の $30 \%$ を 超え, $4.5 \mathrm{~g} \times 4$ 回投与では, $50 \%$ 以上を示し臨 床的効果が期待できる. 一方, 小览への投与に 関する\%TAMなどの成績は報告されていないが, 小児の各年齢群におけるAUCは成人と同等以上 であることから, 小児に拈ける\% 人の 1 日 3 回投与と同程度に設定できると予想 される。

\section{5）カルバペネム系薬}

(1) メロペネム・ドリペネム

2011 年にメロペネム（3 月）とドリペネム (4 月）の 1 日最大投与量 $3 \mathrm{~g}$ (重症感染症) が承認 された．前述のように 関連パラメータはTAMであり, テビペネムを除 くカルバペネム系薬も同様である. 高い\% TAM 值を得るためには, 1 日の投与回数を出来るだけ 増やす，もしくは持続点滴による投与が望まし いが, 1 日最大投与量が低いままであれば, 薬物 血中濃度がMSWを通過する時間が長くなること から, 結果的に耐性菌を選択しやすい. カルバ ペネム系薬は広域スペクトルであり抗菌力も強 いことから，我が国では汎用されていることか ら，その耐性菌の出現に注意しなければならな
い.これら 2 凨の主な副作用としてASTおよび ALTの検查值上昇など肝機能異常が認められる が, これは $3 \mathrm{~g}$ の増量に伴い増加する。 しかし， これらの事象については, いずれも程度は軽度 又は中等度であり, 非重篤である。

高用量カルバペネム系薬は, 重症・難治性感 染症の場合に選択されるが, Empiricalな投与で は3 日目を目安に, 薬片効果を判定し, 継続の 可否を考えるべきである. 効果がみられない場 合, 耐性菌や薬剤の感染巣移行が低い可能性が あげられるため, 薬片の変更を考慮すべきであ り，漫然と使用すべきではない．

おわりに

PK-PD理論は, 血中濃度ベースで考えられて いるが, 実際の感染病巣は各臓器にあり, 抗菌 薬の実力は組織移行性によるところが大きい. 今後PK-PD理論を臨床でより有効活用するため には, 組織中濃度レベルでの議論が必要である.

著者のCOI (conflicts of interest) 開示：藤村 茂 ; 寄付講 座 (杏林製薬, 塩野義製薬, 第一三共, 大正製薬, 大日本住 友製薬, 大鹏薬品工業, 富山化学工業, Meiji Seikaファルマ), 渡辺 彰; 講演料 (MSD, 塩野義製薬, 第一三共, 大正富山 医薬品, ファイザー), 寄付金 (アステラス製薬), 寄付講座 (杏林製薬, 塩野義製薬, 第一三共, 大正製薬, 大日本住友製 薬, 大鵬薬品工業, 富山化学工業, Meiji Seikaファルマ)

\section{文献}

1) Craig WA:Pharmacokinetic/Pharmacodynamic parameters : rationale for antibacterial dosing of mice and men. Clin Infect Dis $26: 1-10,1998$.

2) Mattie H, et al : Determinants of efficacy and toxicity of aminoglycosides. J Antimicrob Chemother 24 : 281-293, 1989.

3）戸塚恭一, 他：小児患者におけるtebipenem pivoxil細粒 のPK-PD解析. 日化療誌 57 (S-1) : 186-191, 2009.

4) Fujimura $\mathrm{S}$, et al : Isoleucyl-tRNA synthetase mutations in Staphylococcus aureus clinical isolates and in vitro selection of low-level mupirocin-resistant strains. Antimicrob Agents Chemother 47 : 3373-3374, 2003.

5) Liu A, et al : Selective advantage of resistant strains at 
trace levels of antibiotics: a simple and ultrasensitive color test for detection of antibiotics and genotoxic agents. Antimicrob Agents Chemother 55 : 1204-1210, 2011.

6) 藤村 茂, 渡辺 彰：第 5 章 レスピラトリーキノロン 系薬の特性比較, レスピラトリーキノロン系薬最前線. 改訂版, ユニオンエース, 東京, 2011,50-63.

7）冨田隆志, 他 : Therapeutic drug monitoring (TDM)に 基づく抗菌薬の適正使用. 日本外科感染症誌 $3: 547-552$,
2006.

8) Fujimura S, et al : Antibacterial effects of brand-name teicoplanin and generic products against clinical isolates of methicillin-resistant Staphylococcus aureus. J Infect Chemother 17 : 30-33, 2011.

9）藤村 茂, 他：臨床分離されたPseudomonas aeruginosa に対する arbekacinの抗菌力 (2003 年〜2007 年). 日化療 誌 $57: 91-96,2009$. 